\title{
INSERTION COMMERCIAL SECTOR AND COMPETITIVENESS IN ARGENTINA: AN ANALYSIS ABOUT THE POSSIBILITY OF DEINDUSTRIALIZATION OF ECONOMICS
}

\author{
INSERÇÃO COMERCIAL SETORIAL E COMPETITIVIDADE \\ NA ARGENTINA: UMA ANÁLISE SOBRE A POSSIBILIDADE DE \\ DESINDUSTRIALIZAÇÃO DA ECONOMIA
}

\author{
Michael Gonçalves da Silva(*) \\ University of Santa Maria, Santa Maria (RS), Brazil. \\ Clésio Lourenço Xavier ${ }^{(* *)}$ \\ University of Uberlândia, Uberlândia (MG), Brazil. \\ Vanessa Siqueira Peres da Silva ${ }^{(* * *)}$ \\ University of Santa Maria, Santa Maria (RS), Brazil.
}

\begin{abstract}
Resumo: Em razão da alta demanda mundial de bens intensivos em recursos naturais, nos anos recentes, este artigo objetiva averiguar, por meio da análise da balança comercial, como seu deu a inserção comercial da Argentina entre os anos 2000-2011. Usando os critérios de agregação setorial proposta pela Organização para a Cooperação e o Desenvolvimento Econômico (OCDE), quanto à classificação de intensidade tecnológica, se verificou que o crescente comércio argentino foi obtido de setores produtores de bens fora da indústria, e crescentes déficits comerciais em outros setores da economia. Estes resultados podem indicar uma possível desindustrialização da economia.
\end{abstract}

Palavras chaves: Desindustrialização, venda de intensidade comercial e tecnológica.

Abstract: Due to high global demand for goods intensive in natural resources, in recent years, this article aimed to measure, through the analysis of the trade balance, as Argentina's economy, between the years 2000-2011. Using the sectoral aggregation proposed by the Organisation for Economic Co-Operation and Development (OECD), classification of technological intensity, it was established that the Argentine economy growing trade balances obtained for the sectors producing non-industrial goods, and growing trade deficits with the other sectors of the economy. These results may point to a possible de-industrialization of the economy.

Key words: Deindustrialization; and Technological Intensity Balances commercial.

(*) Economist at the Federal University of Santa Maria. PhD Program Graduate in Economics from the Federal University of Uberlândia. E-mail: <michael_gsilva@yahoo.com.br>.

(**) Doctor, Associate Professor at the Federal University of Uberlândia and Researcher Productivity CNPq.E-mail:<clesio@ ufu.ie.br>.

$(* * *)$ Master, Assistant Professor at the Federal University of Santa Maria. PhD Student Graduate in Statistics and Agricultural Experimentation of the Federal University of Lavras. E-mail: <spvanessa@yahoo.com.br>. Received in 08.05.2013, approved in 27.11.2013. 


\section{INTRODUCTION}

The growing demand for industrial goods not in the 2000s, due to the growth of the economies of the east, has raised a number of questions about the form of the other emerging commercial insertion. In this context, the issue of de-industrialization of these economies has gained more space, since the high-technology sectors have lost ground in the export to non-industrial sectors.

Thus, when considering the analysis of trade integration, you can see which sectors, classified according to the Organization for Economic Cooperation and Development (OECD), grew, or not, between the years in question. The results may show the involvement of industry in international trade, contributing to check for evidence of de industrialization of the economy.

The objective of this paper is to discuss about the evidence of deindustrialization process of the Argentine economy vis-à-vis their integration into international trade.

The research will be literature and empirical analysis with data from international trade. The research is qualitative technique, imprint explanatory. The database used is that of SITC UN/UNCTAD to generate disaggregated data to three digits, in the recent period.

The paper is structured as follows: in addition to this introductory section, other four sections will be covered.

An initial review of the theories of trade and international integration, the following will be a brief discussion about the deindustrialization of the economy, then we discuss some indicators of the country and, ultimately, international trade data will be disaggregated and re-aggregated using the SITC to OECD proposal of sectoral aggregation, obtaining thus business performance information. The final remarks expose a summary of results and conclusions.

\section{COMMERCIAL INTEGRATION: A BRIEF REFLECTION OF THEORIES OF INTERNATIONAL TRADE}

Regarding International Trade David Ricardo in his theory of comparative advantage states that countries should produce what present higher relative productivity. In the Ricardian model of trade, the differences between countries with respect to relative prices, are due to differences between the demands of labor. As these requirements are contained in the Ricardian model, the costs of labor are too. Therefore, demand conditions do not determine the pattern of trade in the case of two countries and two goods.

DAVIS (1996) argues that the theorem of Stolper and Samuelson ${ }^{(1)}$ to become observable in empirical work should have as a reference not only the factor endowments of

(1) The Stolper-Samuelson theorem states that if the labor input is abundant, for example, an increase in the relative price of the good leads to a more than proportional increase in the price of the factor used intensively in the production and declining real income of the other factor. 
a country in relation to the rest of the world, but should still relativize the appropriations of a country only in comparison with other countries which have similar allocations. These groups to identify the author uses the concept of cone diversification. He explains that the factor endowments between countries restrain the equality of factor prices.

CIMOLI (1988) shows that the pattern of trade measured based on trade flows can be assessed according to the process of technological convergence and divergence. That is, the innovation process is responsible for the technological divergence observed between countries, and imitation and diffusion are responsible for the convergence between them. As innovations arise, the country can gain through Ricardian rents due to the process of technological divergence, which gives the setting conducive to economic growth, depending on the degree and persistence of its divergence. Already in countries converge technologically, the Ricardian rents tend to disappear.

CANUTO (1998) presents a theoretical model of the interaction between trade and growth with foreign exchange constraint, in which specialization patterns, structures associated with productive sectors of two different countries, play a fundamental role, since the sectoral dynamics differentiated relation to technological innovation and imitation (allied to specific income elasticities of demand and prices of each sector) affect economic growth. The model proposed by this author believes that the growing trade between North-South is given by the technological gaps and the product cycle of Vernon $^{(2)}$. It is the variability in patterns of specialization of countries that differentiates your model.

So to the author, the model consists based on the following considerations: productivity changes become specific to sectors, and no more to countries; nominal wages are indexed to average increases in productivity; import demand and export, similar Keynesian models of growth with foreign exchange restrictions ${ }^{(3)}$; allow up negative trade balances by net inflows in the capital account. Thus, the intensification of technological innovation is responsible for the divergence between North and South The higher the level of innovation found in the northern countries the greater the divergence in specialization patterns of countries, the faster the process occurs imitation and diffusion innovations faster the process of divergence will lead to the convergence between the countries.

CURADO and FERNÁNDEZ (2011) analyze the pattern of trade specialization Argentina between 1990 and 2010. Their results were compared with Brazil while in the second there is a process of (re) insourcing and reduction of technological intensity of exports, the first is an increase in industrial exports with increased participation of the medium-and high-tech exports fall Low technology.

XAVIER (2001) argues that Keynesian literature indicates that differences in income elasticity and price elasticity of exports and imports are specific to countries and

(2) Vernon part of this concept and articulates a theory of trade that points to a notion of comparative advantages of dynamic character and a theory of investment (productive) assumes bounded rationality and market structure in imperfect competition (CANUTO, 1998).

(3) The model assumes national uniformity, preferably in relation to: consumption, income and wage rates. In the absence of international credit, the balance of the balance of payments occurs due to equal spending between North and South. 
constrain economic growth for the country, as can be seen in THIRLWALL (1979) and MCCOMBIE and THIRLWALL (1994).

THIRLWALL (1979) states that in a situation of stability in the real exchange rate and the economy functioning below full capacity occupation, the reason for the growth rate of household income relative to income from the rest of the world is conditioned by reason of income elasticity of demand for exports on the income elasticity of demand for imports. This relationship is known as "Thirlwall's Law": the rate of long-term growth of an economy is given by the rate of long-term growth of its exports divided by the long-run elasticity of demand for imports.

To MCCOMBIE and THIRLWALL (1994) is that there is also a priori reasons to expect at least a degree of exogeneity of income elasticities, rather than its complete incorporation by the process of economic growth: the endowment of natural resources, the presence of path dependence and the degree of technological learning, among others. Thus, productivity increases would be determined by the growth rates and not the reverse, resulting in a balance of payments constraints limiting the growth of domestic demand and income.

KRUGMAM (1987) argues that international trade fosters the emergence of the nascent industry, because with the increase in revenues from exports of goods intensive in natural resources, capital accumulation increases, favoring the emergence of industrialization and thus replacing imports. According to the author, the developing economies have potential comparative advantage in manufacturing, but still do not have enough strength to compete with international trade. These infant industries should receive, temporarily, government assistance until they are able to compete with international competition. Thus, the marketing of goods in the economy with other countries is associated with comparative advantages the country possesses; your trade pattern is measured based on their trade flows.

Their analysis dealing with international trade enables more noticeable the factors responsible for the existence of the mailing process of deindustrialization of the economy, which will be dealt with below.

\section{CONCEPTS ABOUT THE ECONOMY DEINDUSTRIALIZATION}

The term deindustrialization is recurrently used to refer to the relative loss of industry in employment and income. The evidence of deindustrialization process manifest in a reversal of the exports of a country, which is the most immediate result of this process. Thus, it is interesting to make a brief reflection of some authors who discuss the characteristics of deindustrialization in the economy.

CLARK (1957) argues that this process of de industrialization of the economy occurred in developed countries, due to the increased demand for services at the expense of demand for manufactured goods, as per capita income tended to increase.

To NASSIF (2008) discussion about the deindustrialization is derived from two policies: import substitution and trade liberalization, combined with high international prices of commodities. 
OREIRO and FEIJOO (2010), submitted after the definitions of deindustrialization, say, does not necessarily have a negative impact, because the reduction in the share of industry in product and employment generation, is accompanied by an increase in the tariff of export of products with higher technology, industrial dynamics is not affected.

The reprimarization economy, according to GONÇALVES (2001), is the loss of international activity of manufactured products, and the gain of agricultural products exported, or is the change of export structure with the largest relative share of agricultural products, and smaller share of manufactured.

ROWTHORN and RAMASWAMY (1999) deindustrialization is mainly explained by factors that are internal to the advanced economies, that is, as a result of interactions between changing patterns of preference between manufacturing and services, the fastest productivity growth in manufacturing in compared to services and the associated decline in the relative price of factory.

To TREGENNA (2008), deindustrialization is usually defined as a decline in manufacturing as a share of total employment. From a perspective of deindustrialization kaldoriana, could have negative implications for long-term growth, given a particular manufacturing growth properties.

LIKEWISE; DE NEGRI (2005), economies in the process of deindustrialization, products classified as commodities or labor-intensive are the ones that contribute to the generation of positive trade balances. On the other hand, products of medium and high-technology, and do not contribute to the trade surplus, also have very high deficits.

ROWTHORN and RAMASWAMY (1999), to analyze the evolution of industrial employment in 18 developed economies, found that since 1970 these countries have experienced a reduction in the share of industrial employment in total employment of 10 percentage points, reaching the level of $18 \%$ in 1994. Although the period and the speed with which this process began have occurred differently across countries, the authors sought to pinpoint its causes and implications. Explanations for the shift of manufacturing employment in the service sector do not differ much from the explanations in the early stages of development when there is a reduction of employment in agriculture, either from the perspective of demand and the supply side.

The explanation on the demand side is given by the change in income elasticity, while in the case of supply justifications converge to productivity growth. With respect to productivity, ROWTHORN and RAMASWAMY (1997) point out that despite the difficulty of measuring productivity in the service sector, it is undisputed fastest growing industrial productivity, making the service sector follow absorbing this labor released, even to follow the growth of industrial output.

TREGENNA $^{(4)}$ (2009 apud OREIRO; FEIJÓ, 2010) defines the deindustrialization as a situation in which both industrial employment and the value added of industry

(4) Tregenna, F. Characterizing deindustrialization: an analysis of changes in manufacturing employment and output internationally. Cambridge Journal of Economics, Cambridge, v. 33, n. 3, p. 433-466, 2009. 
reduces the proportion of total employment and gross domestic product (GDP), respectively. Moreover, deindustrialization is a discussion pertaining to the bulge of heterodox literature that considers the prospect of sectoral composition is crucial for growth.

CLARK (1957) refers to the deindustrialization can be seen as a decrease in the share of employment in industry, incurred by the incorporation of new technologies that increase productivity. It is also characterized by decreased manufactured goods in output and employment compared to other sectors, especially the service.

Four explanations are found in Palma (2005) about the deindustrialization: outsourcing of productive activities, shifting labor to industrial services, reduction of income elasticity of demand for manufactured goods, increased productivity in the industry of Information Technology and Communication (ICT), new international division of labor.

So after this brief theoretical reflection about the settings of the process of de industrialization of the economy will be addressed in the next section, a brief discussion of the Argentine economy in recent years.

\section{ARGENTINA ECONOMY DURING RECENT}

The early 2000s in Argentina was marked by a backdrop of severe economic crisis never before seen in the country ${ }^{(5)}$. Thus, in a scenario of economic crisis are noted significant declines in industrial performance of a country, ie the country's aggregate demand decreases.

Considering the Gross Domestic Product (GDP) as an indicator of economic performance, its decline is related to the reduction of industrial production, thus the graph 1 shows the performance of Argentina's GDP between the years 2000 and 2011.

Given the graph it is evident the sharp decline in GDP in 2002 reflected the Argentine economic crisis, by which the country went through. Since 2002, one can observe that GDP has a uptrend until the year 2011, with a small decline in 2009, due to the global crisis of 2008, but quickly resumed its upward trend for the years beyond.

(5) For better understanding of the performance of the Argentine economy in the 90s and 2000 refer Vadell (2006). 


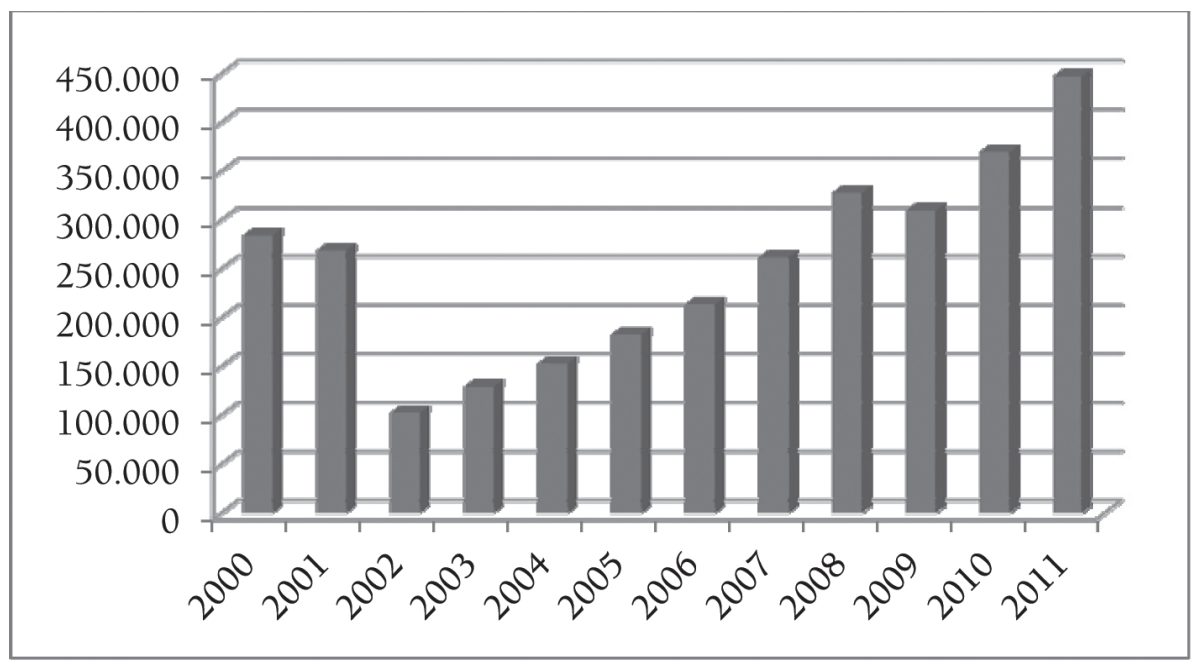

GRAPH 1

Gross Domestic Product at Current Prices in Argentina (in Billions) between 2000-2011

Source: International Monetary Fund, World Economic Outlook Database, April 2012

Another variable of great importance for understanding the industrial performance of a country's investment rate. In general we can define the rate of investment as a relation between investment and gross domestic product of each country, i. e.:

$$
I=\frac{\text { Investimento }}{P I B}
$$

Graph 2 illustrates the behavior of the rate of investment in the Argentine economy between the years 2000-2011. As the behavior of GDP, its trajectory has a reduction for the years 2002 and 2009, also related, in a way, the consequences of the crisis of the Argentine economy and world respectively.

Thus, it is evident that the rate of investment in the country presented an upward trend since 2002, surpassing the 25\% to GDP, this data demonstrate a strong relationship with the Gross Domestic Product. 


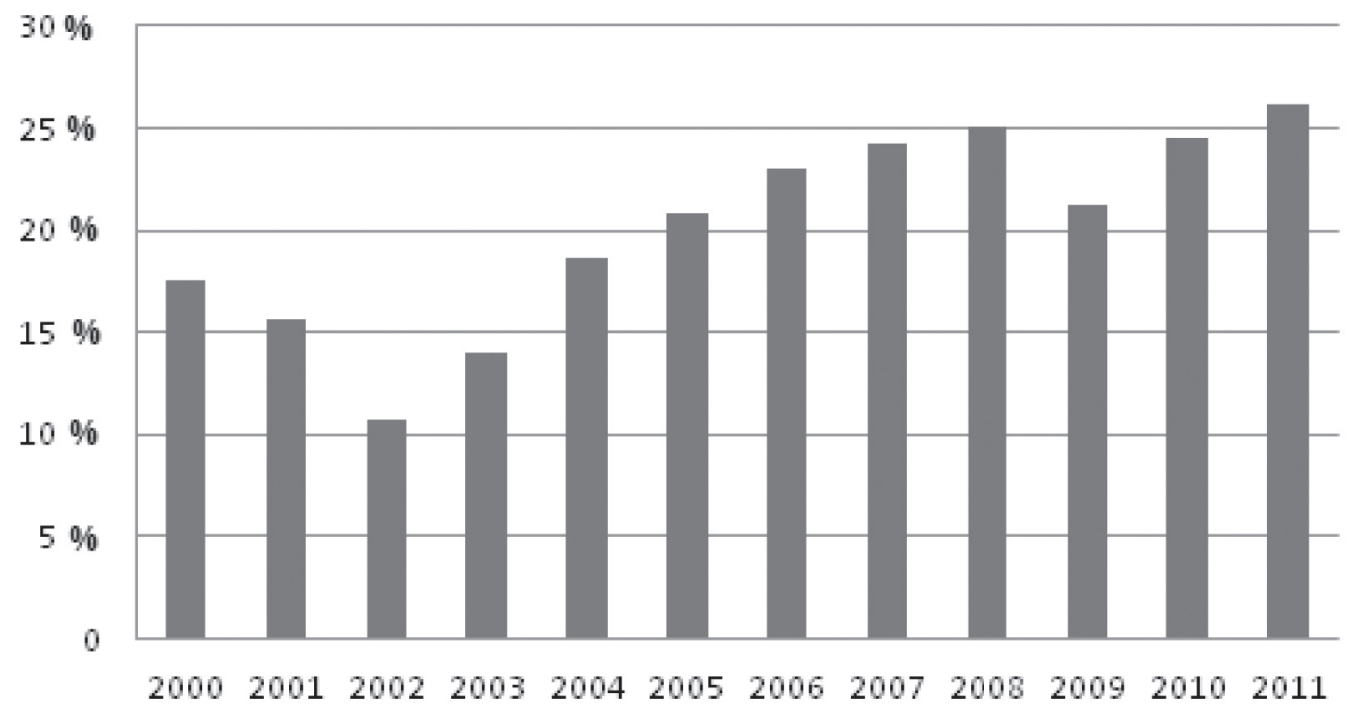

GRAPH 2

Rate of InVestment ECOnOmics Argentina between 2000-2011 in Terms (\%) Source: International Monetary Fund, World Economic Outlook Database, April 2012.

Given the information about the behavior of GDP and the investment rate in the Argentine economy, both have had an upward trend during the period in question. Thus, considering that the increased levels of investment are responsible for generating employment and income and consequently raise the product given economy, the graph 3 aims to present the behavior of the unemployment rate in the country in recent years.

Defining unemployment rate (A) as the ratio between the number of unemployed in the economy (D) and labor (L) in the economy in the current period, so we have:

$$
A=\frac{D}{L}
$$

Thus, the graph 3 shows the employment rate in the Argentine economy between the years 2000 and 2011, considering the effects of the 2001 economic crisis in the country, responsible for reductions in GDP and the investment rate in 2002 to this year, the unemployment rate also rose. The following year, there is an increasing tendency to fall in the same, i. e., past the post crisis in this country, the investment rate and GDP grew by generating jobs and income, thereby reducing the rate of unemployment in the economy. 


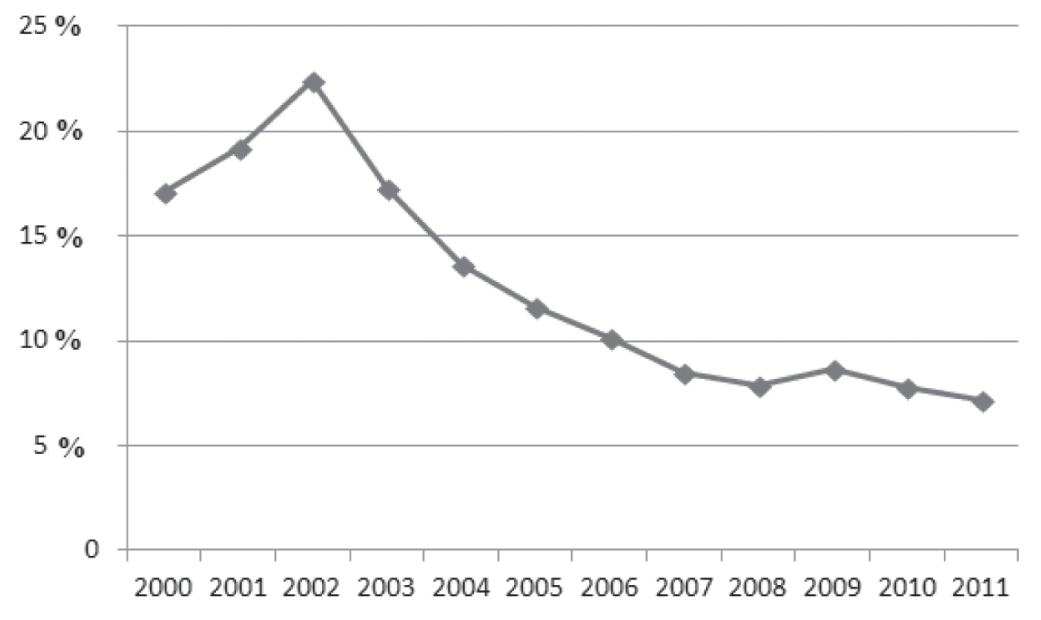

GRAPH 3

\section{Unemployment rate Economy Argentina between 2000-2011 in (\%)}

Source: International Monetary Fund, World Economic Outlook Database, April 2012.

Therefore, when analyzing the indicators of GDP, investment rate and the unemployment rate of the Argentine economy in the years 2000-2011, it can be concluded that after the period of economic crisis, the country showed a favorable trend for the economy. However, such data analyzed so far are presented in aggregate form, ie not tell which were the sectors that contributed most to the results shown here.

Thus, the following discussion will focus on the analysis of sectoral trade balances, will be used for both the sectoral aggregation methodology proposed by the Organisation for Economic Co-Operation and Development (OECD), trade data will be obtained from the UNCTAD/COMTRADE disaggregated to three digits.

\section{BALANCES AND COMMERCIAL SECTOR COMPETITIVENESS}

The method of aggregating data from the Organisation for Economic Co-Operation and Development (OECD) measures the technological intensity of industrialized products. Your rating is very simple and allows to evaluate the degree of technology export basket of a country. The sectors that the classification of OECD aggregates are: non-industrial products, industrial products with low technological intensity; industrial products of low-medium-tech, industrial products of medium-high-technology, industrial products of high technological intensity, and other products. This classification will be useful in the evaluation of the intensity of the composition of exports and trade balances of the Argentine economy, aiming to analyze the trade structure of the country. This aggregation methodology will be used in this section.

The sector "non-industrial" is what comprises most products from agriculture, as well as consider other natural resource-intensive commodities. Briefly, the main sectors of "non-industrial products" are: food (fruits, seafood, grains, dairy, eggs etc.), Crude 
oil and its derivatives also in the raw state, leather and furs, precious stones, raw animal and vegetable oils and oleaginous seeds, fertilizers and mineral origin, cork and wood, rubber in its raw state, metal ores, cement, lime, asbestos and building materials in general, refractory and coal and coke.

The next is the manufacturing sector, comprised of low-tech industries, which can be listed as follows: pulp and paper industry, beverages and tobacco, paper and packaging, textile yarn, metal works and artifacts, manufactures leather, fur, rubber manufactures, processed oils used in food of animal and vegetable fats and waxes, travel articles, furniture and mattresses, clothing and accessories, footwear, glasses, ceramics, natural and manufactured gas, electric power, steel and iron and nonferrous metals.

The industrial sector comprised of low-medium-tech sectors include capital goods, namely machinery and equipment sector, and transport vehicles (cars, motorcycles, bicycles and the like) and transport iron, plastics and paints.

Segments of medium-high technology industries include producers of equipment and scientific instruments and chemical industry gross.

The high-technology segment includes pharmaceutical, electronic precision, radioactive materials, aeronautics and the like. Based on the information in Table 1, the next step will be (re) aggregating data according to the classification of the OECD.

\section{Table 1 - Classification OECD}

\begin{tabular}{|l|l|}
\hline \multicolumn{1}{|c|}{ NOMENCLATURE } & \multicolumn{1}{c|}{ SECTORS OF ACTIVITY } \\
\hline Non-industrial products & $\begin{array}{l}\text { Live animals, minerals, oil, gas, mineral } \\
\text { grains and perishable foods etc. }\end{array}$ \\
\hline $\begin{array}{l}\text { Industrial products with low technological } \\
\text { intensity }\end{array}$ & $\begin{array}{l}\text { Traditional industries: pulp and paper, beve- } \\
\text { rage, food, clothing, furniture, leather and } \\
\text { footwear. }\end{array}$ \\
\hline $\begin{array}{l}\text { Industrial products of low-medium-tech } \\
\text { Included in this classification: durable con- } \\
\text { sumer goods, such as electronics, automo- } \\
\text { biles. }\end{array}$ \\
\hline $\begin{array}{l}\text { Industrial products of medium-high techno- } \\
\text { logical intensity }\end{array}$ & $\begin{array}{l}\text { Capital Goods: machinery and equipment, } \\
\text { petrochemical, metallurgy, fuel etc. }\end{array}$ \\
\hline $\begin{array}{l}\text { Industrial products of high technological in- } \\
\text { tensity }\end{array}$ & $\begin{array}{l}\text { Fine chemicals, telecommunications, preci- } \\
\text { sion instruments etc. }\end{array}$ \\
\hline
\end{tabular}

Source: Organization for Economic Co-Operation and Development (2010).

By aggregating the data of Argentine exports we obtain the results in Graph 4, where it is possible to verify that in all sectors exports showed elevations, especially the non-industrial sectors, low and low-medium technological intensity. The sectors of 
medium-high and high technological intensities grew well below the other sectors of the economy. This is evident in the graph below.

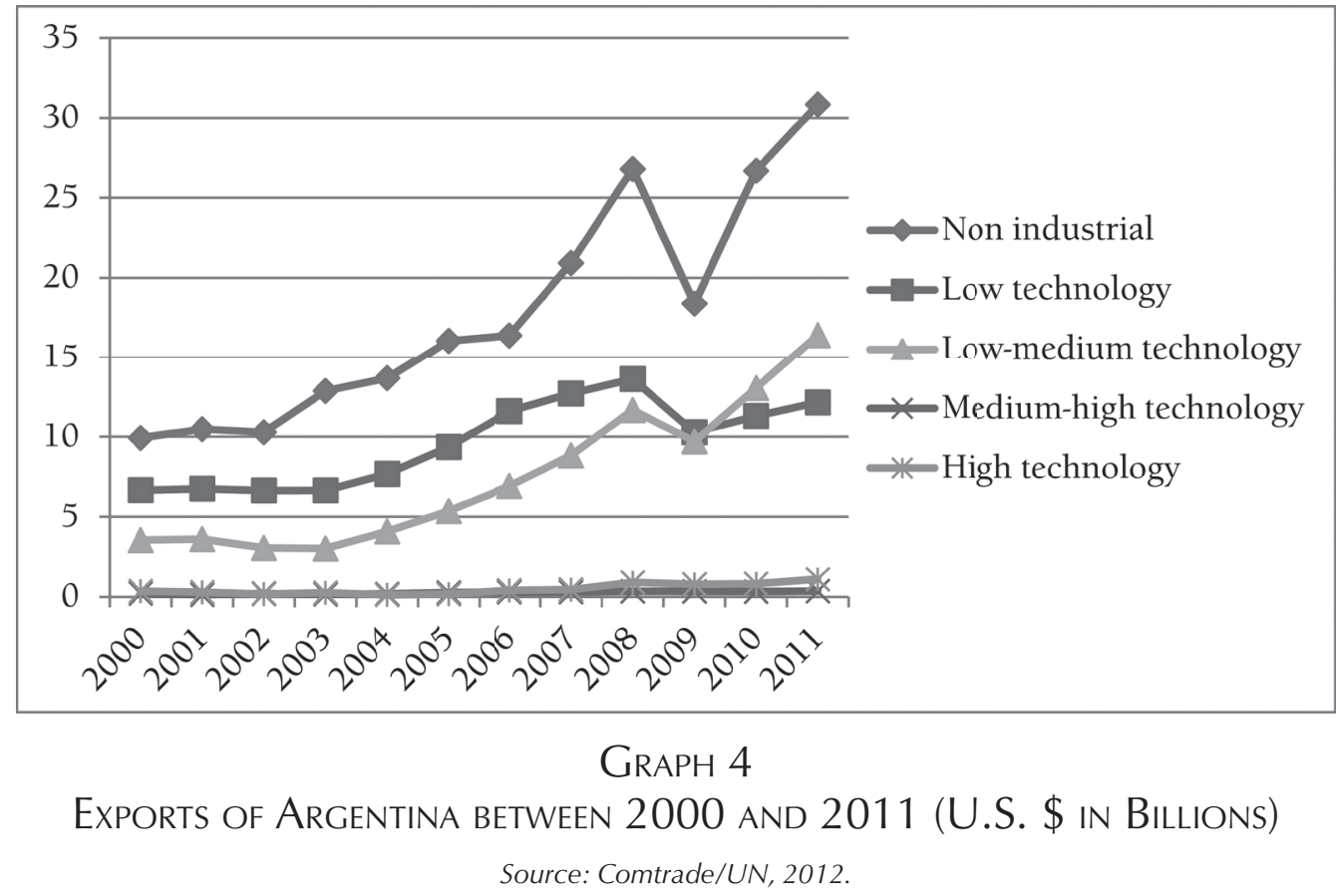

To include imports, the results obtained with the data grouping of trade balances are illustrated in Figure 5. According to the same, it is evident that the non-industrial sector was the sector that showed growing trade balances for the period in question. This result mainly by rising international commodity prices due to the increase in demand from countries like China in recent years.

The sectors with low, low - medium, medium-high technological intensity were the sectors with the biggest decline for the period in question, especially since 2002. The high-technology sector showed less variance in performance, although, like the others, except for non-industrial, obtained with rising deficits.

Thus, it is evident that even with favorable indicators Argentina's economy (GDP and investment rate increasing and decreasing unemployment rate), when analyzed its trade integration demonstrates the increasing import of goods with higher technological intensity, ie the participation of industrial goods imported in the economy has increased, leading to the loss of domestic industry competitiveness. 


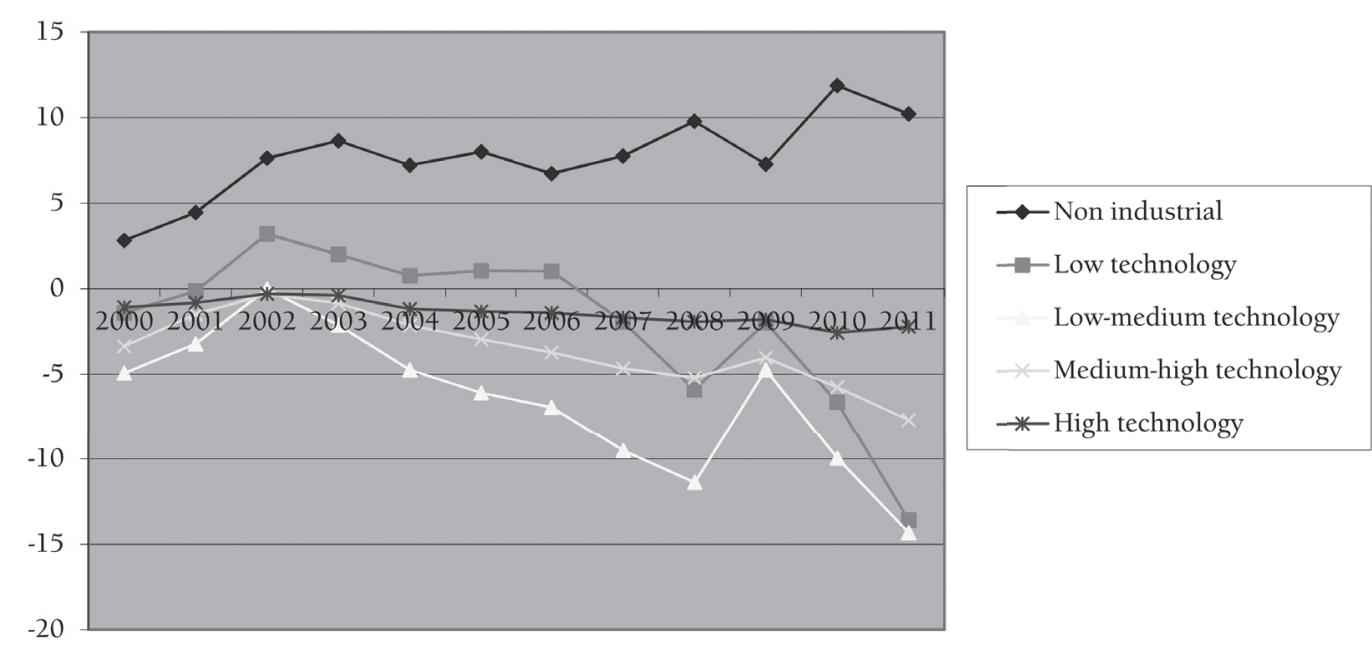

\section{GRAPH 5}

Trade Balances in Argentina between 2000 and 2011 (U.S. \$ In Billions)

Source: Comtrade/UN, 2012.

Gonçalves (2001) argues that reprimarization economy is the loss of international activity of manufactured products, and the gain of agricultural products exported and De Negri (2005) by asserting that deindustrialization is associated with growing trade balances of non-industrial products considering the analysis of these authors the Argentine economy could be going through a process of deindustrialization.

Therefore, the deindustrialization of the economy can be attributed not only to developed countries as proposed by Clark (1957) and Rowthorn and Ramaswamy (1999), but the countries that have natural resources endowment and degree of industrialization of its economy, in which the occurrence of shocks when the demand for industrial goods not occur changes in sectoral trade balances of the economy.

\section{CONCLUSION}

The growth in global demand for agricultural commodities and minerals boosting their international prices is presented as an opportunity for countries natural resource intensive. This can lead to channeling resources investment to sectors intensive in natural resources to the detriment of the industry.

When analyzing exports of Argentine economy can be seen that the non-industrial sectors, low and low-medium technological intensity showed increasing results, others (medium-high and high-technology) also increased their exports, but a proportion much smaller.

In assessing the country's trade integration, ie to include imports, it was evident that the country had increased trade balances in non-industrial sectors and rising deficits in the industrial sectors. These results differ from the analysis Curado and Fernández 
(2011), because the authors considered only the export performance and not trade balances.

Thus, when assessing the balance of trade is possible to understand how a country that is part of the global trade and if the trade deficits of the industrial sectors continue decreasing and non-industrial sectors remain with growing surpluses in the long run, the economy can Argentina face a process of deindustrialization.

\section{BIBLIOGRAPHY}

CANUTO, Otaviano. Patterns of specialization, technological gaps and growth with foreign exchange constraint. Journal of Political Economy, São Paulo, v. 18, n. 3 (71), p. 5-15, july/set. button. 1998.

CIMOLI, Mário. Technological gaps and institutional asymetries in the North-South model With the Continuum of Goods. Metroeconômica, Bologna, v. 39, n. 03, p. 245-274, October 1988.

CLARK, Colin. The conditions of economic progress. London: MacMillan, 1957.

CURADO, Marcelo; FERNÁNDEZ, Virginia Laura. An analysis of the pattern of trade specialization of Argentina. Magazine Economics and Technology (RET), v. 8, n. 2, p. 103-116, april/june 2012.

DAVIS, Donald. Trade Liberalization and Income Distribution. National Bureau of Economic Research. Working Paper, n. 5693, 1996.

GONÇALVES, Reinaldo. International competitiveness and regional integration: The hypothesis of the insertion regressive. Journal of Contemporary Economics, Rio de Janeiro, v. 5, special issue, 2001.

INTERNATIONAL MONETARY FUND. Home Page.

Available at HTTP: <www.imf.org>. Access: august 5, 2012.

KRUGMAN, Paul. The narrow moving band, the Dutch Disease, and the Consequences of Mrs. Thatcher competitive. Journal of Development Economics, Amsterdam, v. 27, n. 1, p. 41-55, 1987.

MCCOMBIE,Jhon.; THIRLWALL, Anthony. Economic growth and the balance-of-payments constraint. London: Macmillan, 1994.

NEGRI, Fernanda de. Technological content of Brazilian foreign trade: the role of foreign companies. Discussion Paper, n. 1074, Brasilia: IPEA, 2005.

NASSIF, André. There is evidence of deindustrialization in Brazil? Journal of Political Economy, v. 28, n. 1, p. 72-96, 2008.

OREIRO, José Luiz; FEIJÓ, Carmem. Deindustrialization: definition, causes, effects and the Brazilian case. Journal of Political Economy, v. 30, 2010.

ORGANIZATION FOR ECONOMIC CO-OPERATION AND DEVELOPMENT. Home page. Available at: <http://www.OCDE.org>. Access: august 15, 2012.

PALMA, Gabriel. Four sources of 'de-industrialization' and a new concept of the 'Dutch Disease. In: OCAMPO, José Antônio. Beyond Reforms: structural dynamics and macroeconomic vulnerability. Stanford University Press and World Bank, 2005.

ROWTHORN, Robert; RAMASWAMY, Ram. Deindustrialization: causes and implications. International Monetary Fund, Staff Studies for the Economic Outlook, 1997.

THIRLWALL, Anthony. The balance of payments constraints to an explanation of international growth rate differences. Banca Nazionale del Lavoro-Quarterly Review. Roma, v. 32, n. 128, p. 45-53, march 1979. 
TREGENNA, Fiona. Characterizing deindustrialization: an analysis of changes in manufacturing employment and output Internationally. Cambridge Journal of Economics. Oxford, v. 33, n. 3, p. 433-466, may 2009.

UN COMTRADE. United Nations Commodity Trade Statistics Database. Statistics Division. Available at: <http://comtrade.un.org>. Accessed on: 13 june 2010.

VADELL, Javier. Alberto. The international political and economic conditions in Argentina Néstor Kirchner. Available at <http://www.ucm.es/info/eid/pb/07Vadell-T.pdf>. Accessed: august 2012.

XAVIER, Clésio Lourenço. Patterns of Specialization and Trade Balances in Brazil. Article Presented at the XXIX National Meeting of Political Economy — Anpec, 2001. 